\title{
Study Tentang Pemberdayaan atau Penggunaan Alat Musik Sederhana Pada Kegiatan Bernyanyi di TK Wesley Kota Kaban Jahe
}

\author{
May Sari Lubis ${ }^{1,}$ Isa Hidayati ${ }^{2}$, Siska Priskilla Kaban ${ }^{3}$ \\ ${ }^{1,2}$ Dosen Prodi PG PAUD, Universitas Negeri Medan, \\ ${ }^{3}$ Mahasiswa Prodi PG PAUD, Universitas Negeri Medan \\ Jl. Willem Iskandar Medan, Sumatera Utara, Indonesia \\ ${ }^{a)}$ E-mail : Maysarilubis27@unimed.ac.id
}

\begin{abstract}
Abstrak: Penelitian bertujuan untuk melihat dan menggambarkan efektivitas guru dalam mengembangkan kecerdasan musik anak usia dini melalui kegiatan bernyanyi dengan menggunakan alat musik oleh guru maupun peserta didik pada PAUD yang berada di Kecamatan Kaban Jahe Kabupaten Karo yakni TK Wesley Kota Kaban Jahe. Jenis penelitian yang digunakan adalah penelitian kualitatif deskriptif. Metode yang digunakan dalam penelitian ini adalah metode observasi, wawacara, dan studi dokumen. Penelitian ini dilaksanakan pada bulan oktober 2021 dalam satu kali kegiatan dengan subjek penelitian guru dan siswa-siswi TK Wesley Kota Kaban Jahe. Berdasarkan data yang diperoleh, guru di TK Wesley Kota Kaban Jahe belum sepenuhnya dapat mengembangkan dengan baik kecerdasan musik anak usia dini dengan pemanfaatan alat musik saat kegiatan bernyanyi. Hasil penelitian ini diharapkan dapat dijadikan bahan kajian para guru dalam menerapkan penggunaan alat musik dalam kegiatan bernyanyi serta menjadi acuan bagi pendidik anak usia dini dalam dalam menyiapkan program peningkatan kompetensi pendidik anak usia dini di bidang pengembangan kecerdasan musik anak usia dini.
\end{abstract}

Kata Kunci: kegiatan bernyanyi, alat musik, Anak Usia Dini

\section{Pendahulan}

Kegiatan bernyanyi merupakan hal yang tidak asing lagi bagi setap manusia, nahkan bernyanyi merupakan hal yang tidak dapat dipisahkan dari kehidupan manusia karena hampir setiap orang melakukan kegiatan bernyanyi dalam kesehariannya. Begitu juga dengan pendidikan anak usia dini, kegiatan bernyanyi tidak bisa dilepaskan dari pendidikan anak usia dini. Kegiatan bernyanyi merupakan menyanyikan suatu lagu dan tentunya lagu sangat erat kaitannya dengan musik. Lagu adalah gumparan seni atau nada yang diurutkan, dikombinasikan, hubungan temporal yang biasanya diiringi dengan alat musik untuk menghasilkan suatu musik yang mempunyai kesatuan dan kesinambungan yang mengandung irama. Ragam nada atau suara yang memiliki irama disebut dengan lagu. Musik tidak dapat dipisahkan dari kata bunyi dimana musik itu sendiri dapat didengarkan melalui bunyi. Musik adalah bunyi yang atur dan membentuk suatu pola sehingga dapat enak didengar telinga yang selanjutnya mengkomunikasikan perasaan dan suasana hati. 
Seni musik (Jamalus) adalah hasil karya seni berupa bunyi yang dituangkan dalam bentuk lagu atau komposisi yang dituangkan sebagai ungkapan perasaan dan pikiran penciptanya melalui unsur-unsur pokok musik yaitu melodi, irama harmoni dan struktur lagu serta ekpresi sebagai bentuk kesatuan. Selain itu (Bernstein dalam picker dalam dofi, 2010 :6) mengungkapkan bahwa musik merupakan suara-suara yang diorganisasikan yang memiliki nilai seni yang diguakan sebaai alat untuk mengekspresikan ide dan emosi bagi setiap pendengarnya. Jelas bahwa musik sangat erat kaitanya dengan emosi seseorang, bahkan musik dapat mengatur suasana hati seseorang. Dengan mendengar musik orang dapat menjadi bersemangat, dengan mendengar musik orang dapat menjadi sadar dan dengan mendengar musik orang dapat diingatkan kembali dengan suasana-suasana tertentu artinya musik sangat mempengarui otak manusia sehingga pada pendengar musik dapat mengkomunikasikan perasaanya atau emosinya melalui musik. Menurut Di Corrine, Mme dan Stael (Djohan: 2010: 45) musik memiliki daya untuk menyegarkan dan memperkuat ingatan yang hampir pupus, hal ini juga berkaitan dengan musik adalah penghayatan isi hati manusia yang diungkapkan dalam bentuk bunyi yang teratur dengan melodi atau ritme serta mempunyai unsur atau keselarasan yang indah (Sunarko, 1985: 5), dari pendapat ahli tersebut dapat disimpulkan bahwa musik dapat memberikan rangsangan dengan pengaruh yang baik pada perkembangan emosi anak usia dini dan otak anak. Berbicara mengenai musik pada anak usia dini tidak terlepas dari kegiatan bernyanyi, pengambangan kecerdasan musik yang baik pada anak usia dini tentunya melalui kegiatan bernyanyi. Pendidikan anak usia dini bernyanyi merupakan kegiatan yang tidak bisa terlepas dari PAUD karena hampir semua kegiatan bermain di PAUD selalu diselingi dengan kegiatan bernyanyi, oleh karena itu sudah seharusnya seorang guru PAUD menguasai Teknik bernyanyi dengan baik dan mengetahui poin-poin apa yang disampaikan kepada anak didik sebelum mengajak anak memulai kegiatan bernyanyi. Menurut Djohan 2009 terdapat beberapa aktivitas yang umum dilakukan dalam pendidikan musik untuk anak anakyaitu senagai berikut:

1. Bernyanyi, untuk membantu perkembangan anak dalam artikulasi pada ketrampilan bahasa irama dan kntrol pernapasan.

2. Bermain musik, membantu pengembangan dan koordinasi kemana pun motori. Mempelajari sebuah karya musik dengan cara memmainkannya dapat mengembangkan ketrampilan musik serta membangaun rasa percaya diri dan disiplin diri.

3. Gerak ritmis, digunakan untuk mengembangkan jangkauan fisiologis, menggabungkan mobilitas/ ketangkasan/ kekuatan keseimbangan koordinasi, konsistensi, pola-pola pernapasa, dan relaksi otot. 
Dari ketiga poin yang telah dijelaskan diatas maka dapat dikatakan bahwa kegiatan bernyanyi merupakan kegiatan terpenting pada PAUD selain menjadi bagian dalam kegiatan velajar-mengajar di PAUD kegiatan bernyanyi juga menjadi stimulus yang baik untuk merangsang perkembangan anak usia dini. Selain memberikan stimulus yang baik untuk otak bernyanyi juga membantu anak usia dini mengkoordinasi geraknya dan keseimbangan anak usia ini. Selanjutnya kegiatan bernyanyi ini sebgai fasilitas untuk membangun dan membiasakan anak percaya diri dan sebagai alat untuk melihat minat bakat anak di bidang musik maka dari sinimguru dapat melatih dan mengembangkan bakat musik pada anak. Jika dlihat dari begitu banyaknya manfaat musik bagi perkembangan anak dapat dikatakan bahwa kegiatan bernyanyi ini sebagai alat bantu para pendidik dalam mengoptimalkan aspek-aspek perkembangan anak. Jadi sebaiknya dan sudah seharusnya guru PAUD memiliki ketrampilan musik yang cukup baik untuk dapat memberikan kegiatan bernyanyi yang bai pula kepada anak. Selain menguasai Teknik bernyanyi alangkah lebih istimewanya jika seorang guru PAUD memiliki keahlian memainkan suatu alat musik. Karena alat musik menjadi bagian yang sangat diperlukan dalam kegiatan bernyanyi, sebagai pengiring dimana anak dapat dilatih mengikuti ketukan yang benar adalam bernyanyi. Alat musik yang rata-rata dimiliki dan disetiakan disekolah adalah keyboard dan gitar namun rata-rata guru PAUD belum memiliki kemampuan dalam menggunakan alat ini yang seharusnya dapat digunakan mengiringi anak dalam kegiatan bernyanyi. Padahal dengan bantuan alat musik sangat membantu guru dan siswa dalam menentukan nada yang tepat dan menentukan ketukan yang serentak dalam bernyanyi. Lagu-lagu di PAUD adalah lagu yang sederhana yang memungkinkan guru dapat mengiringi dengan menggunakan akord primer. Dengan dapat menemukan nada dasar yang tepat tentu kegiatan bernyanyi menjadi kegiatan yang sangat menyenangkan dan membiasakantelinga untuk menirukan suara yang didengar akan melatih danmengasah musikalitas anak. Menurut Lwin,dkk (2008:147) yang mengemukakan bahwa anak pada usia di bawah 10 tahun perkembangan otaknya masih berkembang dan dapat dibentuk sehingga perlu dilakukan beberapa cara agar potensi musik pada anak dapat dikembangkan. Adapun cara yang dilakukan diantaranya : Memperdengarkan kepada anak pilihan musik yang beragam. Mendengarkan musik secara singkat akan memabntu anak mengembangkan fokus dan merangsang imajinasi awal dan keterampilan berpikir abstrak. Pilihan musik yang sesuai untuk anak dapat membantu anak untuk belajar lebih baik. Lagulagu yang diperdengarkan kepada anak akan memberikan pengaruh terhadap perkembangan otak anak. Hal itu terjadi karena otak berkembang sesuai dengan pola yang ada dalam musik. Semakin rumit pola suara musik makan semakin besar pula anak dapat belajar. Musik dapat diperdengarkan sebagai latar belakang untuk meningkatkan konsentrasi, memusatkan perhatian, membangkitkan semangat, atau berfungsi sebagi 
transisi anytara akhir sebuah topik dan permulaan topik. Untuk anak usia dini hal itu wajib dilakukan karena dunai anak merupakan dunia yang menyenangkan. Sehingga anak akan lebih mudah memahami konsep materi yang diberikan melalui lagu. Contoh jenis musik yang dapat digunakan untuk latar belakang pembelajaran adalah musik santai, musik bertema nuansa untuk membangkitkan semangat anak, musik dari budaya yang berbeda yang sesuai untuk anak. Selanjutnya yaitu, mendengarkan musik dan menyanyikan lagu disertai gerakan. Musik merupakan suatu cara simbolis untuk mengekspresikan perasaan diri manusia. Tidak hanya dengan musik saja, gerakan yang berupa tarian juga efektif digunakan untuk mengekspresikan suasana hati. Bergerak mengikuti irama musik membantu meresapi konsep musikal yang didengarkan. Dengan bergerak anak biasa mengungkapkan perasaannya dan mengendalian nafsu dan keterampilan.

Dari pemaparan sejumlah teori yang telah dijelaskan maka disimpulkan bahwa kegiatan bernyanyi merupakan kegiatan yang tidak bisa dipisahkan dari PAUD yang dapat menjadi stimulus yang membentuk perkembangannya lebih baik dan dalam kegiatan bernyanyi haruslah disertai alat musik. Tidak jarang memang ditemui kegiatan bernyanyi disertai alat musik namun kegiatan bernyanyi akan lebih sempurna jika dimanfaatkan alat musik sebagai pengiringnya terutama untuk anak usia dini dalam mengembangkan kecerdasan musiknya, maka dari itu para peneliti ingin melihat bagaimana pengunnaan dan pemberdayaan alat musik saat ini dalam keggiatan bernyanyi Anak Usia Dini di TK Wesley Kota Kaban Jahe.

\section{Metode}

Jenis penelitian yang digunakan dalam penelitian ini adalah penelitian kualitatif deskriptif. Menurut Arikunto (2010) penelitian deskriptif yaitu suatu penelitian yang bertujuan untuk memberikan gambaran atau memaparkan sesuatu hal, misalnya keadaan,kondisi, situasi, peristiwa, kegiatan dan lain-lain, yang hasilnya nantinya dituangkan dalam bentuk kata-kata. Adapun yang ingin dipaparkan dalam penelitian ini adalah pembedayaan atau penggunaan alat musik pada kegiatan bernyanyi anak di TK Wesley Kota Kaban Jahe.

Metode yang digunakan untuk pengumpulan data dalam penelitian ini adalah wawancara, observasi, dan studi dokumen. Metode wawancara dalam penelitian ini digunakan untuk mendapatkan data tentang cara guru melaksanakan kegiatan bernyanyi dengan menggunakan alat musik pada anak usia dini. Metode observasi digunakan untuk mengamati berlangsungnya kegiatan bernyanyi oleh anak. Dalam pelaksanaan pengumpulan data penelitian, metode observasi diwujudkan dengan teknik lihat, simak dan catat. Teknik lihat disini digunakan untuk melihat cara guru memulai dan melaksanakan kegiatan bernyanyi pada anak di TK Wesley Kota Kaban Jahe. Teknik simak disini 
digunakan untuk menyimak bagaimana keadaan saat kelangsungan kegiatan bernyanyi oleh guru bersama anak-anak. Teknik catat digunakan untuk mencatat hal-hal penting berkaitan dengan pemberdayaan atau penggunaan alat musik pada kegiatan bernyanyi anak sekaligus mencatat hal-hal penting berkaitan dengan keadaan maupun proses bernyanyi anak di TK Wesley Kota Kaban Jahe. Metode studi dokumen digunakan untuk menelaah kesiapan guru dalam memfasilitasi kegiatan bernyanyi pada anak.

Data yang sudah didapatkan dikumpulkan kemudian dianalisis menggunakan 3 alur yang dilakukan secara bersamaanyaitu reduksi data, penyajian data, dan verivikasi data (Miles dan Huberman 2014). Pada tahap reduksi data peneliti merangkum data, memilih hal-hal yang menjadi pokok, mengfokuskan kepada data data yang penting dicari tema, alur dan polanya dan memnyisihkan data yang tidak begitu diperlukan. Data yang telah direduksi akan memberikangambaran jelas dan memudahkan peneliti untuk melakukan pengumpulan data selanjutnya dilakukan. Pada tahapan penyajian data, peneliti membuat urauan singkat mengenai data yang telah direduksi untuk menemukan temuan penelitian. Pada tahap verivikasi peneliti peneliti meninjau kembali data yang telah diperoleh dan disajikan dalam bentuk narasi, untuk melihat kembali masih ada atau tidak adanya data yang belum sesuai dan diteliti kembali lalu membuat kesimpulan yang sesuai dengan buktibukti yang pada penelitian.

Adapun subjek yang diteliti dalam penelitian ini adalah guru wali kelas TK B yang melaksanakan melaksanakan kegiatan bernyanyi bersama anak dan siswa-siswi TK B Wesley Kaban Jahe. Objek dalam penelitian ini yaitu pemberdayaan atau penggunaan alat musik dalam kegiatan bernyanyi pada anak si TK Wesley Kota Kaban Jahe.

Penelitian ini dilakukan selama 1 bulan sampai dengan selesai pada bulan oktober tahun 2021 yang dilakukan dalam beberapa kali kegiatan bernyanyi guru bersama anak, dilanjutkan dengan kontribusi kegiatan bernyanyi yang dilakukan peneliti kepada anak di kelas TK B Wesley Kota Kaban Jahe, dimana peneliti sekaligus melakuakan wawancara terhadap guru, yang selanjutnya peneliti melakukan observasi kegiatan bernyanyi pada anak di kelas TK B Wesley Kota Kaban Jahe.

\section{Hasil dan Diskusi}

3. 1 . Kegiatan Bernyanyi Anak Usia Dini

Berdasarkan data yang sudah diperoleh peneliti, ditemukan bahwa TK Wesley Kota Kaban Jahe sudah melakukan kegiatan bernyanyi secara rutin di kelas. Hal dilihat dari wawancara yang dilakukan kepada pendidik yaitu wali kelas TK B, yang menyatakann kegiatan bernyanyi di kelas dilakukan setiap kali sebelum memulai pembelajaran dan sesudah selesai kegiatan pembejaran. Kegiatan bernyanyi pada anak dapat dikatakan berlangsung bagaimana semestinya dimana setiap kali pada saat kegiatan bernyanyi anak selalu bersemangat dan mengikuti kegiatan bernyanyi dari awal lagu hingga selesai. Selain itu setiap kali kegiatan bernyanyi berlangsung anak selalu dapat mengikuti gerakan dari 
lagu yang dinyanyikan, namun pada saat memulai suatu lagu para siswa-siswi besrta guru kurang begitu kompak dalam menentukan ketukan lagu dan ada anak yang ikit bernyanyi namun nadanya berbeda dengan teman-temannya. Campbell (2003:10) mengemukakan metode bernyanyi adalah anak-anak merasakan kebahasiaan ketika mereka bergoyang, menari, bertepuk dan menyanyi bersama seseorang yang mereka percayai. Inilah alas an mengapa anak dapat bersemangat dan membuat gerakan-gerakan pada saat bernyanyi. Wali kelas TK B juga mengungkapkan pada kegiatan bernyanyi anak disekoalah tersebut belum/jarang sekali ,menggunakan alat musik baik itu alat musik asli maupun alat musik sederhana yang dibuat sendiri. Kegiatan bernyanyi di TK Wesley Kota Kaban Jahe tetap berjalan sebagai rutinitas namun memiliki kekurang dalam kreativitas bernyanyi karena kegiatan bernyanyi hanya dilakukan dengan menyanyikan suatu lagi tanpa diiringi alat musik yang digunakan guru maupun yang digunakan siswa-siswi. Memang kegiatan bernyanyi telah dapat sebagai wadah anak dalam menuangkan perasaan ataupun emosinya dimana anak-anak selalu bersemangat dalam kagiatan bernyanyi. Seperti yang diungkapkan oleh Honing (1988) Mengemukakan bahwa sejak lahir anak secara biologis sudah dilengkapi dengan kesenangan untuk merespon suara-suara orang. Dari pendapat tersebut menunjukkan kegaitan bernyanyi merupakan kegiatan yang disenangi anak-anak karena bernyanyi merupakan bakat yang bersifat alamiah yang dimiliki seta dibutuhkan p;eh setiap individu. Hal inilah yang menyebabkan walapun kehiatan bernyanyi dilakukan dengan seadanya saja namun anak-anak dapat mengikuti dengan bersemangat dan rasa senang walaupun dari segi pendengar kurang sempurna. Padahal seperti banyak teori yang sudah dibahas bahwa penggunaan alat musik pada kegiatan bernyanyi anak sangat memberikan pengaruh untuk keberhasilan capaian tujuan pada kegiatan bernyanyi yang dilaksanakan seperti ungkapan Memberi kesempatan kepada anak untuk memainkan instrumen musik, alat musik sangat penting. Dengan bernyanyi diiringi oleh alat musik dapat membantu guru dan siswa dalam mencari nada yang tepat, mengenali nada tinggi dan nada rendah, dan dapat menetukan ketukan yang pas dengan kombinasi gerak.

\section{Pentingnya Alat Musik Pada kegiatan Bernyanyi Anak Usia Dini}

Alat musik pada kegiatan bernyanyi anak usia dini memberikan manfaat yang besara dalam kesusksesan pendidik menyukseskan kegiatan bernyanyi yang bukan hanya segedar sebagai pengiring untuk menghidupkan suasana bernyanyi namun sebagai alat bantu para pendidik mengembangkan kecerdasan musikal anak usia dini. Penggunaan alat musik pada kegiatan bernyanyi anak usia dini bukan berarti hanya gurunya saja yang dapat menggunakan alat musik sebagai pengiring namun anak didiknya juga perlu diberikan bermain alat musik yang memberikan rangsangan kepada kecerdasan musikalnya.Alat musik yang dimainkan tidaklah harus alat musik asli namun dapat juga digunakan alat musik sederhana atau alat musik buatan yang dikreasikan. Menurut Lwin, dkk (2008:156) 
terdapat bukti dari MRI bahwa otak musisi yang memainkan perubahan suatu instrumen menyebabkan perubahan psikologis dalam korteks, mungkin dari aktivitas syaraf yang besar jumlahnya yang terjadi ketika bermain musik. Memainkan alat musih anak usia dini, dengan memainkan instrumen musik sendiri dapat memberikan kesempatan pada anak untuk menghasilkan suara. Selain itu bisa juga mengembangkan daya pengamatan dan meningkatkan kecerdasan musikal anak. Sangat disayangkan jika pendidik tidak memiliki keahlian atau pengenalan yang cukup akan musik anak usia dini karena kesempatan mengembangkan kecerdasan musik anak terbuang sia-sia. Pada kegiatan bernyanyi di TK Wesley Kota Kaban Jahe kalau memungkinkan gerakan guru menggunakan tepukan tangan dan atau menepuk meja sebagai ketukan bernyanyi. Namun dari hasil pengamatan yang dilakukan peneliti, kegiatan bernyanyi di TK Wesley Kota Kaban Jahe kurang efektif karena rendahnya pemberdayaan atau penggunaan alat musik pada kegiatan bernyanyi. Pernyataan ini dinyatakan berdasarkan hasil pengamatan dimana guru dan siswa tidak serentak dan kurang kompak dalam bernyanyi, terdapat anak yang bernyanyi dengan nada yang berbeda dengan teman-temannya, dan tidak serentak dalam memulai suatu lagu. Namun peneliti juga melihat bahwa adanya kemampuan anak jika diberikan memainkan alat musik dimana pada saat bernyanyi ada beberapa anak yang bersemangat sampai mengetuk-ngetuk meja saat bernyanyi. Namun sangat disayangkan sekolah belum memfasilitasi pemanfaatan alat musik pada kegiatan bernyanyi. Dari data yang ditemukan peneliti adapun factor yang menyebabkan guru belum menggunakan alat musik dalam kegiatan bernyanyi di TK B Wesley Kota Kaban Jahe, diantaranya :

1. Guru yang membingbing kegiatan bernyanyu di TK tersebut belum memiliki keahlian dalam menggunakan suatu alat musik

2. Kurangnya pengetahuan gutu dalam menggunakan atat musik

3. Guru belum memiliki kesiapan dalam mengiringi anak-anak bernyanyi dengan menggunakan alat musik

4. Sarana dan prasarana alat musik disekolah kurang memadai dan kurang mendukung

5. Pengetahuan guru PAUD akan musik AUD masih minim dikarenakan guru pada TK tersebut bukan lulusan PG.PAUD dan bukan lulusan jurusan yang berbau musik, dan guru yang mengajar disekolah tersebut masih sering berganti-ganti

Berdasarkan pendapat diatas, dapat disimpulkan bahwa kegiatan bernyanyi pada TK B sudah berjalan gimana semestinya anak bernyanyi namun tetap saja masih msmiliki permasalahanpermasalahan yang luamayan sering ditemui seperti pemdidik dan peserta 
didik belum dapat menentukan nada dasar yang sama dan masih sering terjadinya bernyanyi yang kurangs serentak. Dalam hal kegiatan bernyanyi dengan benar pada anak AUD ternyata guru memegang peran yang penting pada kegiatan bernyanyi yang seharusnya dapat sebagai kegiatan yang mengasah kecerdasan musik pada anak. Brnyanyi hanya sebagai hal yang berjalan seperti rutinitas saja namun tetaplah juga dapat dikatakan bahwa kegiatan benyanyi pada anak merupakan kegiatan yang menyenangkan dimana anak tetap dapat bernyanyi gimana mestinya pada saat kegiatan bernyanyi berlangsung.

Bedasarkan hasil wawancara oleh anak usia dini siswa paud yang diwawancarai bersamaan dengan cara wawancara tidak langsung, menyatakan bahwa mereka sudah pernah menggunakan alat musik dalam kegiatan bernyanyi dengan menggunakan alat musik kerincing yang dimainkan oleh guru yang membingbing kegiatan bernyanyi namun sudah jarang bahkan tidak pernah lagi. Sewaktu peneliti mencoba mengajak anak bernyanyi bersama dengan diiringi gitar, anak sangat bersemangat mengikuti alunan gitar dan ketukan bernyanyi dengan menjadi serentak bahkan suasana bernyanyi semakin bersemangat dimana anak-anak menggoyang-goyangkan kakinya lalu menepuk-nepuk tangan dan membuat gerakan pada saat bernyanyi.

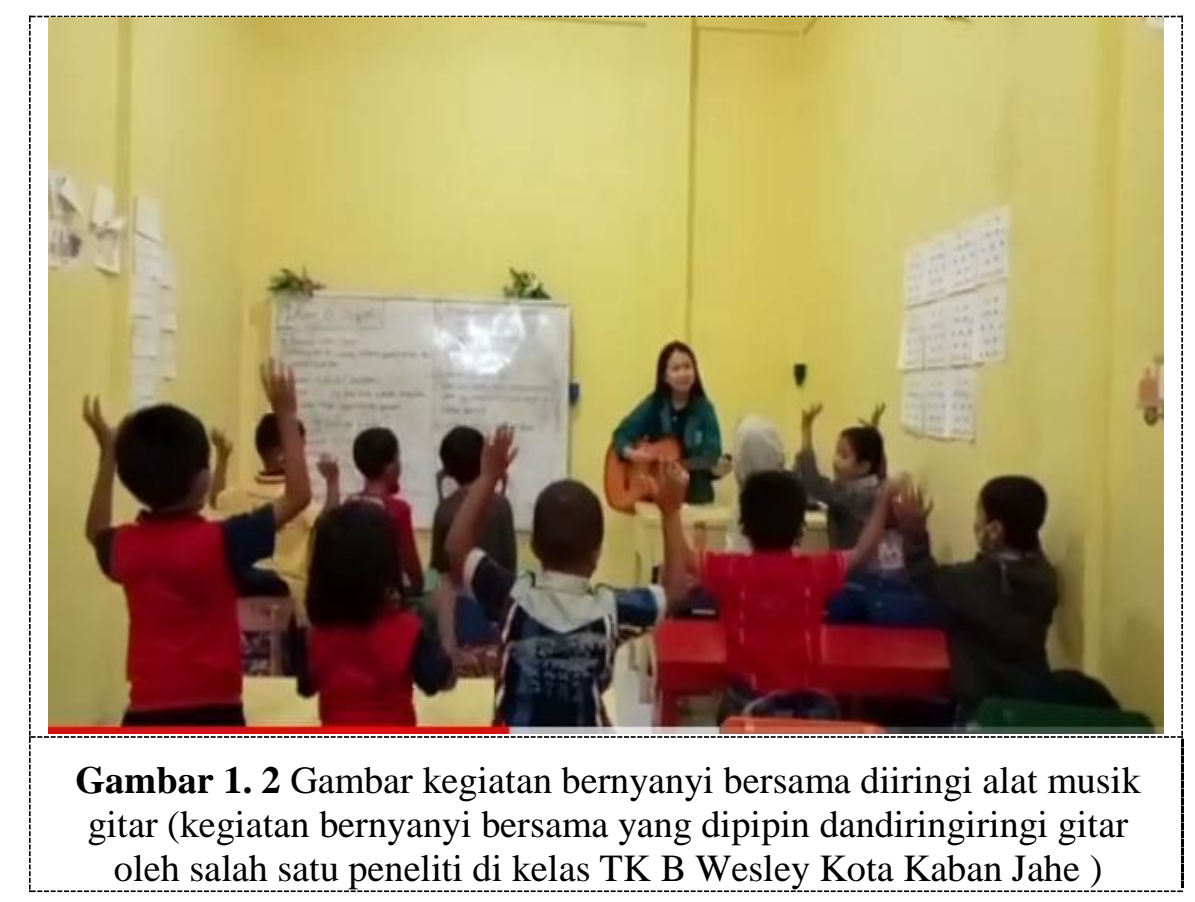

Gambar 1.2 menunjukkan bahwa bernyanyi bersama pada Anak Usia Dini menggunakan alat musk lebih efektif dibandingkan dengan tidak emnggunakan alat musik sama sekali. Menurut ungkapan Lwin (2008:147) yaitu salah satu mengembangkan potensi musik pada anak dapat dilakukan dengan cara mendengarkan musik dan disertai menyanyikan lagu dengan gerakan, musik merupakan cara simbolis untuk mengekspresikan perasaan diri 
manusia. Tidak hanya dengan musik saja, gerak yang berupa tarian juga efektif digunakan untuk mengekspresiskan suasana hati. Bergerak mengikuti irama musik membantu meresapi konsep musikal yang didengarkan. Dari pendapat ahli tersebut bahwa tambahan iringan musik memberikan pengaruh yang besar dalam kegiatan bernyanyi,dimana anak dapat bernyanyi dengan lebih menikmati lagu yang dinyanyikan dan lebih mampu menyeragamkan ketukan dan nada dasar meskipun harus dilakukan beberapa kali percobaan untuk penyesuaian dari yang sebelumnya tidak menggunakan alat musik sebagai pengiring.

Dari kegiatan wawancara dan penagmatan yang dilakukan, bahwa pemberdayaan dan penggunaan alat musik TK Wesley Kota Kaban Jahe belum berjalan dengan baik, dimana dari hasil wawancara dan pengamatan yang dilakukan kepada anak peneliti menyimpulkan:

1. Anak belum pernah diperkenalkan dengan alat msui sederhana

2. Adak belum pernah meminkan alat musik secara langsung maupun alat, usik sederhana

3. Anak jarang diberikan iringan saat kegiatan bernyanyi

Penggunaan alat musik dalam kegiatan bernyanyi anak usia dini sanagtlah penting untuk diperhatikan, karena dalam pendidikan anak usia dini guru betugas membantu memaksimalkan perkembangan anak. Sayang disayangkan jika kegiatan bernyanyi di PAUD kurang bermkna karena dengan kegiatan bernyanyi pendidik dapat sekaligus melatih bakat dan merangsang kecerdasan pada anak usia dini.

\section{Kesimpulan}

Kegiatan bernyanyi merupakan kegiatan yang tidak bisa dipisahkan dari pendidikan anak usia dini, karena semua kegiatan pembelajaran pada Paud menggunakan metode bernyanyi. Kegiatan bernyanyi pada anak usia dini memiliki dampak yang besar dalam menstimulus aspek-aspek perkembangan anak. Kegiatan bernyanyi pada Paud dapat mengembangkan kecerdasan musikal pada anak jika difasilitasi dengan baik oleh pendidiknya. Pada setiap kali kegiatan bernyanyi berlangsung anak dapat mengekresikan perasaannya ataupun emosinya, dan iringan musik dapat sebagai pembantu anak dalam mengendalikan emosimnya pada saat kegiatan bernyanyi berlangsung. Kegiatan bernyanyi di TK Wesley Kota Kaban Jahe sudah dilaksanakan sebagai rutinitas kurang efektif dimana di PAUD tersebut masih minimnya pembedayaan atau penggunaan alat musik pada kegiatan benyanyi anak. Kurangnya pemberdayaan penggunaan alat musik dalam kegiatan bernyanyi di TK Wesley Kota Kaban jahe disebabkan karena kurangnya pengetahuan guru akan musik PAUD dikarenakan bukan lulusan jurusan Paud, belum adanya keahlian guru dalam memainkan suatu alat musik, belum adanya kesiapan guru dalam mengiringi anak untuk bernyanyi, sarana-prasarana alat musik disekolah kurang memadai. Anak usia dini 
sangat menyenangi kegiatan bernyanyi maka dari itu perlu untuk para pendidik meningkatkan kualitas kegiatan bernyanyi menggunakan alat musik. Alat musik yang dapat digunakan bukan hanya alat musik langsung atau asliu namun guru daapt berkreasi menggunakan alat musik sederhana atau alat musik buatan, karena dakam memainkan alat musik bukan hanya harus di guru saja bahkan alangkag lebih baik jika diberikan langsung kepada anak yang memberikan dia kesempatan untuk menyesuaikan kolaborasi lagu dan musiknya, yang dapat merangsang kecerdasan musikal anak. Penggunaan alat musik pada kegiatan bernyanyi anak sangat penting dan lebih efektif dibandingkan jika tidak menggunakan alat musik sama sekali.

\section{Daftar Rujukan}

Adina Sastra Sembiring, Pengetahuan Musik Pendidikan Anak Usia Dini, (Medan ; Universitas Negeri Medan 2017)

Direktorat PAUD, Bermain musik dan gerak, (Jakarta :2020)

Lwin, dkk, cara mengembangkan berbagai komponen kecerdasan(Yogyakarta)

Masitoh, Heny dkk, Strategi Pembelajaran TK (Jakarta : Universitas terbuka, 2007)

Pendidikan dan Pengajaran, Jilid 46, Nomor 1, April 20183, hlm.1-8

Raudha, Pembelajaran Seni Musik Bgi Perkembanagn Kognotif Anak Usia Dini (Hlm. 1121)

Yuliani Nuraini, Sentra Musik dan Gerak, (Kebayoran baru : Indocamp : 2016) 